\title{
Critique of Imperial Reason: Lessons from the Zhuangzi
}

\author{
Dorothy H. B. Kwek ${ }^{1}$
}

Published online: 8 July 2019

(C) The Author(s) 2019

\begin{abstract}
It has often been said that the Zhuangzi 莊子 advocates political abstention, and that its putative skepticism prevents it from contributing in any meaningful way to political thinking: at best the Zhuangzi espouses a sort of anarchism, at worst it is "the night in which all cows are black," a stance that one scholar has charged is ultimately immoral. This article tracks possible political allusions within the text, and, by reading these against details of social, political, and historical context, sheds light on another strand of the Zhuangzi - one that questions prevailing normative values because it is fiercely critical of scholarly complicity with violent imperial territorial consolidation.
\end{abstract}

Keywords The Zhuangzi 莊子 · Imperialism · Politics · Cosmology · Nature · People

\section{Introduction}

Listed in the Han Shu 漢書, a catalogue of the Han 漢 Imperial library, and canonized in the Tang 唐 dynasty as one of the four Daoist classics (Sizi Zhenjing 四子真經) by emperor Xuanzhong 玄宗, who also conferred upon it the title of True Scripture of the Southern Efflorescence (Nanhua Zhenjing 南華真經) (742 C.E.) (Boltz 2001, Zhang 2015), the Zhuangzi's 莊子 historical orbit through ancient halls of power has nonetheless not prevented its perceived political irrelevance today (Van Norden 2015). ${ }^{1}$ Amidst the North Atlantic academy's growing interest in non-North Atlantic texts, ${ }^{2}$ the attention paid to the political implications of Daoist sources tends to alight on the Daodejing 道德經, rather than the Zhuangzi (Crane 2013, Puett 2001).

\footnotetext{
${ }^{1}$ Certainly, unlike Confucianism, it has not returned to the expedient embrace of China's ruling elite (Billioud and Thoraval 2015, Israel 2016). See report by Chris Buckley (Buckley 2014).

${ }^{2}$ In the discipline of philosophy see Chakrabarti and Weber 2016, and Larson 1988; in political theory, Jenco 2017, Dallmayr 1997, Euben 2006, and Williams and Warren 2014.
}

Dorothy H. B. Kwek

kwekd@ cardiff.ac.uk

1 Department of Politics, School of Law and Politics, Cardiff University, Law Building, Museum Ave, Cardiff CF10 3AX, UK 
The Zhuangzi is often seen as actively advocating political apathy, as critical of political involvement tout court. The Zhuangzi's skepticism, it is argued, renders it unable (or unwilling) to provide a moral compass to anchor political judgment and guide political action; at best the Zhuangzi espouses a sort of anarchism (Hansen 2003, Coutinho 2013), at worst it is "the night in which all cows are black," a stance that one scholar has charged is ultimately immoral (Van Norden 2016). ${ }^{3}$ Instead of addressing the Zhuangzi's putative skepticism, which has been abundantly analyzed by scholars, ${ }^{4}$ this article adopts another approach to exploring the political implications of the text.

This article makes a modest interpretive proposal. It shows how the political concerns within certain strands of the Zhuangzi may be illuminated by reading the text against the historical and political conditions of its composition. The article identifies textual allusions to political problems and actions, which are then juxtaposed against illustrative material details of the sociopolitical context derived from historiographical accounts. This tacking back and forth between text and historical context illuminates another interpretative possibility for reading the Zhuangzi, namely, that instead of political apathy or antipathy, at least some of its passages provide a critical commentary on "imperial virtues," that is, "virtues" that the text identifies with the organization and consolidation of an imperial politics. In doing so, the text itself may be seen as a performative attempt to short-circuit a centralizing, nascent imperial discourse.

The article is organized in the following way. After a discussion and justification of interpretive methods ("Methodology"), I address passages that appear to advocate political apathy, and show that taking the Zhuangzi's intended (historical) audience of cultural and political elites into account reveals another interpretation (in "Disengagement from Worldly Affairs [Ren Jian Shi 人間世]"). I trace the political allusions in the Zhuangzi's criticisms of sages and sagely wisdom, and in doing so, show how passages that otherwise appear skeptical or simply puzzling in fact are allusions to imperial consolidation, and criticisms of sagely and scholarly complicity in imperial oppressions (in "The Complicity of Sages and Their Ideals"). The sections that follow explore how the Zhuangzi's mockery of the sage emperors, who were credited with the foundation of (Chinese) civilization, may be read as a performative undermining of legitimizing discourses of sovereignty and empire (in "Cosmos-politics" and "Against Exemplary Sage-Emperors"). The final section illustrates the interpretive possibilities opened up by an attentiveness to the political dimensions of the text. By reading oblique political elements in the Cook Ding (Pao Ding 㧀丁) narrative in relation to historical ritual and political practice, the section offers an admittedly speculative interpretation of the Cook's teaching, an alternative to its frequent rendering as an exegesis of "skillful spontaneity" ("Playful Speculations on Cook Ding").

\footnotetext{
${ }^{3}$ The latter criticism is Mengzi's (Van Norden 2016: 14). For a contrary view see Nelson 2008. It is not entirely clear if the Zhuangzi's political apathy or antipathy is an effect or cause of the text's putative skepticism and/or relativism. Some scholars have seen in the Zhuangzi a value pluralism that is the hallmark of political liberalism (Fraser 2009, 2015; Sturgeon 2015; but see Perkins 2014).

${ }^{4}$ Issues of skepticism and relativism are addressed amply in the literature, for example, Kjellberg and Ivanhoe 1996, Fraser 2009, Raphals 1994a, Ziporyn 2003, Chinn 1997, Allinson 2015, and Soles and Soles 1998.
} 


\section{Methodology}

There are a number of indications that political concerns are not altogether precluded from the Zhuangzi. Earlier interpreters certainly saw a political relevance in the text. LiU An 劉安, imperial kinsman and king of Huainan 淮南, borrowed extensively from the Zhuangzi to compose his treatise on government, Huainanzi 淮南子 (Master of Huainan), which he presented to the Han emperor in 139 B.C.E. (cf. Major, Queen, Meyer, and Roth 2010: 238). ${ }^{5}$ Allusions to the Zhuangzi are also found in the Lüshi Chunqiu 呂氏春秋 (Spring and Autumn Annals of Master Lü), “a legalistic compendium from the third century B.C.E." (Mair 2001: 10). Closer to our time, Joseph Needham argues that the Zhuangzi (like other proto-Daoist texts) was critical of the form of feudalism that existed in China at the time (Needham 1956). Finally, the text of the Zhuangzi itself is full of political figures, mythical or otherwise, such as emperors, dukes, kings, and their advisors, and the last of the Inner Chapters, "For Emperors and Kings (Ying Di Wang 應帝王)," consists of a series of questions on how to govern.

It may be that it is difficult to pin any kind of politics on the Zhuangzi because of the nature of the text. Its mythical creatures, comical old men, talking trees, foolish philosophers, ex-cons, and other figures fleetingly appear to tell a joke or a tall tale, pose a logic puzzle, or impart difficult-to-decipher advice, in lyrical prose. This polyvocal and open form evades interpretive closure (Gentz and Meyer 2015, Tan 2016), and makes it difficult to ascribe to the text any specific or explicitly political position. Its uncertain provenance and complex history of transmission makes it difficult to assign authorial intent and to align the text with the known political views of any historical figure (Chan 2002, Graham 2003, Lin 2003, Liu 1994, Fraser 1997, Jiang 2016, Klein 2011).

The lack of consensus over periodization, however, need not prevent references to the historical conditions of textual composition and transmission, since the material events of imperial formation and consolidation (with which the Zhuangzi engages) are of longue durée. During the Warring States or Zhan Guo 戰國, to which the earliest strata of the Zhuangzi have been assigned, seven kingdoms vied for hegemony. Rulers sought to centralize power as they dissolved noble lineages, and conscripted commoners and refugees for infrastructural projects and increasingly long wars, laying the foundations for the imperial states that followed. Empire was not erected all at once; instead, mechanisms for securing territory, for absorbing and integrating peasant populations through taxation, conscription, and labor, and for channeling scholars and newly dispossessed nobles into administrative service were adopted in piecemeal fashion, evolving in response to internal intrigue and external threats.

The textual interpretation in this article traces allusions to the emergence and consolidation of imperial politics in different parts of the Zhuangzi, including what are known as the Outer and Miscellaneous Chapters of the Guo Xiang 郭象 recension. Though many scholars hold that the Outer and Miscellaneous Chapters are later additions to the corpus, the decision in this article to deal with the entirety of the Zhuangzi is based on the

\footnotetext{
${ }^{5}$ Especially in this chapter "Quintessential Spirit (Jing Shen 精神)" in the Huainanzi: "Specific turns of phrase, technical terminology, and critiques of practitioners of daoyin [導引] (Grandfather Peng's [彭] Ripe Old Agers) and of embittered self-promoting moralists (Confucians) are so close that one could make a fair case for common authorship" (Major et al. 2010: 238). Cf. Roth 2015.
} 
specificities of classical Chinese manuscript culture, in which composite works relied on editors and compilers and were meant to be read alongside a cumulative tradition of textual commentary (Nylan 2016). ${ }^{6}$ A further cautionary note is the need to find some form of consistency that does not derive from the norms of coherence based on a North Atlantic model of authorship predicated on a single authorial voice. This article does not claim that the Zhuangzi, in its entirety, is anti-imperialistic, or that a critique of imperialism constitutes the primary political message of the text. Rather its more modest claim is that we may discern passages and sentiments critical of imperialistic methods in the Zhuangzi. Though these may not necessarily be consistent with other extant passages on the arts of governing, the anti-imperial material is significant enough to warrant analysis. This is especially so since it has thus far been overlooked. This study therefore provides an initial exploration of the politics of the Zhuangzi, and lays the groundwork for future analyses of possible contrary and/or complimentary textual positions.

The article's interdisciplinary reading of the Zhuangzi fuses methods from literary interpretation, historical interpretation, and North Atlantic philosophical practice in order to pay heed to the historical and discursive specificities of the Zhuangzi (Nylan 2016, Defoort 2001, Raphals 1994b). It is rooted in studies of the rhetorical, literary, and imaginary aspects of the Zhuangzi, which are inseparable from its philosophical questions. It is also distantly informed by Quentin Skinner and the "Cambridge School," which stresses historical context in textual interpretation. However, the interpretive work here always begins with a close reading of specific sections of text, and the tracing of political allusions therein.

\section{Disengagement from Worldly Affairs?}

The Zhuangzi contains many passages that appear at first glance to demonstrate a world-weariness that advises disengagement with worldly affairs, or what is labeled today as "politics," and none more apparently than the passages of the Inner Chapter, "Worldly Affairs (Ren Jian Shi 人間世)."

The chapter opens with Confucius dissuading his disciple, YAN Hui 顏回, from offering unsolicited advice to the autocrat of Wei 衛: if YAN Hui criticized the autocrat, he would be executed; but if he went with the flow of courtly politics, he would end up conforming to the standards he had sought to change; finally, if the ruler were of a mind to heed YAN Hui's advice, then he would have had no need of such advice in the first place. ${ }^{7}$ Another anecdote recounts Zigao 子高 lamenting his appointment as an envoy tasked with difficult negotiations. Confucius tells him: since both fate and duty are inescapable, "Absorb yourself in the realities of the task at hand to the point of forgetting your own existence. Then you will have no leisure to delight in life or abhor death" (Zhuangzi 12/10/18-22; Ziporyn 2009: 100). ${ }^{8}$ There are other similar passages

\footnotetext{
${ }^{6}$ On another approach to the coherence of the Zhuangzi as a whole, see De Reu 2015. On the challenges specific to interpreting classical Chinese, see Yu, Bol, Owen, and Peterson 2000.

${ }^{7}$ Confucius' final counsel is gnomic.

${ }^{8}$ This is the Ziporyn translation. For greater consistency I refer to the Watson translation, which includes all of the Outer and Miscellaneous Chapters, but modify or substitute these at times. Textual references to the Zhuangzi follows the numbering system used in Zhuangzi Yinde 莊子引得 (A Concordance to Chuang Tzu) (Hung 1956).
} 
in the chapter. We may simply note that in the penultimate section, a madman sings a song, in Confucius' hearing, about the sage or sheng ren 聖人. Given the circumstances of the age, the madman sings, the sage's best hope is to avoid execution; the sage should stop confronting the world with his virtuosity (respectively, Zhuangzi 12/4/8689, 90-91). Thus, at first sight, the chapter appears to suggest a stance favoring political nonengagement.

However, aside from these explicit exhortations, there is an added layer of significance in the sociopolitical status of its characters. Aside from Confucius and YAN Hui, there is Zigao 子高, who was a minister of the Chu 楚 kingdom; others include Qu Boyu 鿪伯玉, a minister, and YAN He 顏闔, a scholar (Zhuangzi 10/4/53-64). The advice of nonengagement is thus dispensed to a specific social strata, one composed of scholars, ministers, and (potential) administrators. Additionally, the audience or readers of the text would have been, as Michael Nylan notes, "members of the governing elite" (Nylan 2016: 98), especially since "only an estimated ten percent of the entire population commanded basic literacy and numeracy, and no more than a fraction of the literate enjoyed the sort of 'high cultural literacy' that reading the Zhuangzi requires" (Nylan 2016: 101).

The elite status of the characters, as well as that of the presumed audience of the text, takes on special significance when seen in the context of the extraordinary geopolitical changes wrought in the lifetimes of Confucius, Zigao, YAN He, and Qu Boyu. The addressees of the chapter are shi 士 and men of similar status, "common gentlemen in the Zhou [周] aristocracy" trained in military and civil capacities including "ritual, music, archery, charioteering, writing, and mathematics" (Hsu 1999: 583). Over the course of the Spring and Autumn and Warring States periods, the concentration of power in the hands of the monarch and the decline of hereditary noble houses meant waning fortunes for the shi, who became a "new category of administrative staff" (Hsu 1999: 583), appointed as "an extension of royal power" (Lewis 1999b: 604). Shi status came to signify cultural excellence instead, and this "new ideal type" (Lewis 1999b: 604) was one who was able "to gain the attention of the monarch and persuade him to introduce some new practice" (Lewis 1999b: 603). ${ }^{9}$ Victor Mair notes how "Confucius himself best exemplifies the warrior who turns into a literatus" (Mair 2001: 3), and some of Confucius' disciples were likewise shi. Those who were drawn into state service served primarily as administrative officials who were in charge of maintaining population registers, records of taxes and services, and so on. ${ }^{10}$

As we will see below, the service that the shi performed for the ruler often consisted of surveillance, discipline, and punishment exercised over the commoners. The characters in this chapter on "Worldly Affairs" mirror the status of the shi who would have been Zhuangzi's audience or readers. They would have seen that the reservations expressed in the chapter as directed at the advisory and administrative roles they performed for the sovereign. It is not necessarily the practice of politics tout court that is the subject here.

\footnotetext{
${ }^{9}$ Note the differences between persuaders and alliance formers and scholars.

${ }^{10}$ However, unlike successful generals and ministers who "attracted disciples and formed textual traditions" (Lewis 1999b: 642), "[t]he few scholars whose names and careers are preserved do not seem to have had successful political careers" (Lewis 1999b: 641). In the early days of the philosophical "schools" multiple competing centers of political authority meant an economic base that underwrote doctrinal independence, even opposition (Lewis 1999a: 63-79).
} 


\section{The Complicity of Sages and Their Ideals}

The criticism of scholarly collusion with violent territorial acquisition and consolidation is made very clear in several places in the Outer Chapters. One may of course object that administrative practice is quite different from ideals, and that the chapter on "Worldly Affairs" is precisely the lamentation of shi unable to put their principles into action, and that it is regret, chagrin or frustration that the chapter expresses, a condemnation of the age, rather than of shi or their ideals and knowledge. However, Chapter Ten, "Ransacking Coffers (Qu Qie 胠筮)," ${ }^{11}$ explicitly criticizes sagely ideals for their complicity, not just in justifying or legitimizing imperial expropriation, but for producing the very structures through which such expropriation takes place.

In other words, the problem is not just the application of ideals in practice, or the noncompliance of practice with ideals. The ideals themselves are the problem. This may be seen from the following passage from "Ransacking Coffers":

Isn't he whom the common people call a wise man [zhi zhe 知者] in fact someone who piles up loot for a great thief? And he whom they call a sage (sheng zhe 聖 者]) in fact just a guard in the service of the great thieves? How do I know this is so? The state of Qi [齊] was in olden days so densely populated that one could peer over to the neighboring village and hear its dogs and chickens. The territory reached by Qi's fishing nets and plows exceeded two thousand square miles. And in all the shrines and temples, in every province and hamlet and town, there was no corner that was not regulated by the laws [fa 法] of the sages (sheng ren 聖人). Then one day, TIAn Chengzi [田成子] killed the ruler of Qi and took his state. But what he stole was not only the state; with it, he appropriated the laws devised by the sagely wisdom (sheng zhi zhi fa 聖知之法). So although TIAN Chengzi may have been called a thief, he lived as securely as the [legendary] sage-rulers Yao [堯] and Shun [舜]. Smaller states dared not criticize him and larger states dared not attack him, and his family held on to the throne of Qi for twelve generations. Did he not then steal, along with the state of Qi, the rules of sagely wisdom by which to protect his thieving self? (Zhuangzi 23/10/2-24/10/9; Ziporyn 2009: 181-182; with slight modification)

Is this political cynicism? (It does accord with the view of renowned sociologist and political scientist, Charles Tilly [1985], who saw the state as a protection racket and a form of organized crime.) What does the Zhuangzi mean when it says that "what [TIAN Chengzi] stole was not only the state; with it, he appropriated the laws devised by the sagely wisdom," or that, "along with the state of Qi, [he stole] the rules of sagely wisdom by which to protect his thieving self'? How can laws get stolen? The formulation suggests that it is not simply a case of "sages" pandering to the new ruler, but something more fundamentally problematic, something that touches upon the very constitution of the state.

Indeed political entities underwent drastic changes as the Zhuangzi was composed and compiled, and these changes had significant consequences on the lives of the common people. Political authority was increasingly decentralized during the Zhou

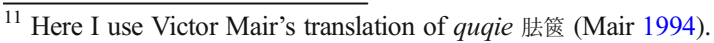


dynasty (1046-256 B.C.E.), and devolved to noncontiguous garrison states with a large rural hinterland serving local hegemons. By the time of the Warring States, rulers had extended and tightened their control over the countryside, drafted rural populations into the military, levied new taxes, and were undertaking large-scale infrastructural projects such as roads and irrigation. Wars became more ferocious and extended. In the Spring and Autumn period wars lasted a day or two; by the time of the Warring States they often lasted more than a year, with battles fought primarily by large infantry armies composed of expendable peasants (Lewis 1999b: 625).

The shi were actively involved in military recruitment for these wars, with the authority to punish noncompliant commoners. They themselves were appointed according to formalized rules. Legal documents found in Yunmeng 雲夢 reveal that the Qin 秦, which later conquered other warring states to form the first empire, had concocted complex institutional means to extend administrative capabilities into the rural hinterland while retaining oversight of officials; annual statistical reports to assess officials' effectiveness, "guidelines for official conduct," as well as "procedures for the inspection of officials" (Lewis 1999b: 609-610) centralized bureaucratic knowledge and discipline. $^{12}$

Commoners were drawn into systems of surveillance by and service to the state. In the Zhou, commoners had no family names. By the 6th century B.C.E. the assignation of family names enabled a systematic registration of the population (Lewis 1999a: 2526). Reforms instituted during the Warring States in the Qin included the organization of peasant households into units of five to ten households "for mutual responsibility and surveillance." If any one hid a defector, all households received the military punishment for surrendering to an enemy; those who reported the culprit reaped the rewards soldiers would receive for enemies' heads in battle (Lewis 1999b: 611). The measures "devoted to the control and mobilization of the rural populace" were administered by a vast army of officials.

In light of such historical verities, the Zhuangzi's objections to sages and their laws are in fact a statement of a profound politico-philosophical problem, namely, the contingency of knowledge vis-à-vis the political problems it is called upon to resolve. What are the ends to which the knowledge of how to govern is applied? The point is made polemically: the sageliness that orders and organizes the state in fact makes it easier for the usurper and tyrant to assert their control. Zhuangzi makes problematic the efficacy of governance itself.

Whether the efficacy of governance is always desirable is questioned in this passage:

So as long as the great robbers continue to go scot-free-as long as these feudal lords continue to be exalted - they will keep stealing benevolence [ren 仁] and appropriate conduct [yi 義] together with the weights, measures, scales, balances, tallies, and seals that ensure their advantage. (Zhuangzi 24/10/17-18; Ziporyn 2009: 184$)^{13}$

\footnotetext{
${ }^{12}$ Independent officials were given "salaries measured, and partially paid, in grain; rewards of gold and silver for meritorious service; seals and tallies to bestow and withdraw authority; numerical accounting procedures to examine officials; regular methods of making appointments" (Lewis 1999b: 606).

${ }^{13}$ Here I replace Ziporyn's translation of $y i$ 義 as “righteousness" with Nylan's “appropriate conduct” (Nylan 2016: 97).
} 
Here the Zhuangzi joins the normative knowledge of ideals (benevolence and righteousness) to mundane and technical forms of knowledge. Contemporary scholarship tends to categorize the former as a normative discourse, and the latter as a utilitarian one; "weights, measures, scales, balances, tallies, and seals" seem merely "valueneutral" tools, neither good nor bad in themselves, but rather instruments that can be put to ends either good or bad.

Historical record shows how the standardization of units of measure- the proliferation of "weights, measures, scales, balances, tallies, and seals"-made it possible for officials to make "statistical reports on stocks of grain, registered population, land opened to cultivation, tax and labor services collected, and pubic security," with nonadherence punishable by fines (Lewis 1999b: 609). It was precisely technical knowledge or techne, and its standardization, that made it possible for shi to serve as representatives of state authority, in the remote control and quasi-imperial penetration of rural hinterlands. The peasants' compliance, and the fruits of their corvée labor, were the objectives of these measures and the objects of measurement. It is no coincidence that the development of these measurements at the same time corresponded to "the first discussion of Warring States law in its classic form" in Fa Jing 法經 (Canon of Laws), and that this law should be "an extended code devoted to penal measures to control the people" (Lewis 1999b: 605-606).

Whatever political efficacy the scholars exercised would not so much be directed "upward," in advising or even reforming rulers, but rather "downward," in enforcing the compliance of the commoners. This is ironically alluded to in the Zhuangzi: "He who steals a belt buckle is executed, but he who steals a state is made a feudal lord" (Zhuangzi 24/10/19-20; Ziporyn 2009: 184). It is possible that this is the Zhuangzi's criticism of the gap between what the shi say and what they actually do, the gap between their ideals and their actions, or that it is a criticism of the hypocritical preferential treatment of political superiors. Thus one possible reading of the passage is as a criticism of scholars who sold their services to territorial rulers (Needham 1956).

However, the Zhuangzi seems to be making a more radical claim, namely, that ideals themselves are a real source of the problem. According to the Zhuangzi, sages themselves are tools or weapons ( $q i$ 器). Hence:

Cut off sageliness, cast away wisdom [ $z h i$ 知], and then the great thieves will cease. [...] Burn the tallies, shatter the seals, and the people will be simple and guileless. Hack up the bushels, snap the balances in two, and the people will no longer wrangle. Destroy and wipe out the laws that the sage has made for the world, and at last you will find you can reason with the people [ $\min$ 民]. (Zhuangzi 24/10/22-24; Watson 2013: 71)

In both passages quoted, zhi 知, which can be translated as "knowledge" or "wisdom," has direct political consequences. The matter cannot be resolved simply by saying that the reality or practice of governing has fallen short of ideals. It is the ideals and norms themselves that are the problem. The Zhuangzi implies that sagely discourse, the discourse of benevolence and appropriate conduct, is inseparable from a discourse of stately efficacy. In other words, sagely ideals are complicit with an oppressive discourse of discipline and efficacy. This is why the Zhuangzi recommends the complete 
eradication of sagely laws (Zhuangzi 24/10/24), and casting aside "benevolence" and “appropriate conduct" (rang qi ren yi 攘棄仁義; Zhuangzi 24/10/27). ${ }^{14}$

In the chapter on "Ransacking Coffers" the Zhuangzi places ideals and principles (benevolence, appropriate conduct) on the same plane as mundane, technical ways of knowing, because the two modes of knowledge have the same effect. This effect is what matters. This is reinforced elsewhere. In the Outer Chapter, "Webbed Toes (Pian Mu 駢 拇)" compares attempts to inculcate benevolence and appropriate conduct to the tearing apart of webbed toes and the cutting off of extra digits; the following chapter, "Horses' Hooves (Ma Ti 馬蹄 )," describes how the practice of benevolence and appropriate conduct leads to the destruction of the dao and its virtue - for which the sage is squarely to be blamed (Zhuangzi 23/9/14). The damage done by the sages is couched in terms of a violation of dao.

Sages, their laws, and their knowledge or wisdom, are the problem: "The sage brings little benefit to the world, but much harm." Thus within a short space the Zhuangzi calls for punishment, even death, to sages: "Cudgel and cane the sages and let the thieves and bandits go their way; then the world will at last be well ordered!" "[I]f the sage is dead and gone, then no more great thieves will arise. The world will then be peaceful and free of fuss. But until the sage is dead, great thieves will never cease to appear" (Zhuangzi 24/10/15-16).

This emphatic condemnation, which spins into violent hyperbole, is a response to the problems brought about by sages and their conduct. And these, as we will see in the following section, are problems of cosmic proportions.

\section{Cosmos-politics}

The Zhuangzi does not just condemn sages and their sagely wisdom for the governmental, administrative, and disciplinary functions they served. The wisdom of the sages, and a concomitant inordinate grasping after knowledge, is depicted at the end of the chapter "Ransacking Coffers" as part of a great cosmic derangement that throws birds, beasts, fishes, the sun, moon, mountains, and rivers into disarray:

As long as men in high places covet wisdom but are without the Way [hao zhi er $w u$ dao 好知而無道], the world will be in great confusion.

How do we know this is so? An abundance of knowledge about crossbows and arrows, traps and nets, and other contraptions, drives birds to a tumult [luan 亂] in the sky. An abundance of knowledge about hooks, bait, nets, poles, and lures drives fish to a tumult in the waters. An abundance of knowledge about traps, nets, snares, and lattices drive beasts to a tumult in the marshes. And knowledge turns into cunning, like a kind of gradual poisoning, rigidifying and unmooring "hard" and "white," disjoining and muddying "sameness" and

\footnotetext{
$\overline{{ }^{14} \text { The entire sentence reads rang }}$ qi ren yi, er tian xia zhi de shi xuan tong yi 攘棄仁義, 而天下之德始玄同矣. Xuan tong 玄同 is difficult to translate. Watson translates it as "mysterious leveling," Ziporyn as "oblivious unity," and Legge, "mysterious excellence” (Watson 2013: 71; Ziporyn 2009: 186; Legge 1891). It also occurs in Chapters 15 and 56 of the Daodejing, and sample translations (out of the 300 available, cf. Kohn 2012) include "dark identity" (Lau 1994), "mysterious union" (Henricks 1989), "profoundest consonance" (Ames and Hall 2003).
} 
"difference," baffling the commoners with disputation and sophistry. Thus it is that each and every great derangement [da luan 大亂] of the world is caused by the coveting of knowledge. [...] Everyone understands enough to reject what they consider bad, but not enough to reject what they consider good. This is the reason for the great disorder, which violates the brightness of the sun and moon above and melts away the vital essence of the mountains and rivers below, toppling the ordered succession of the four seasons in between. All creatures, down to the smallest wriggling and fluttering insects, have thus lost touch with their inborn natures. How profoundly the coveting of knowledge [hao zhi 好知] throws the world into tumult! (Zhuangzi 25/10/34-40; Ziporyn 2009: 188)

It is true that the Zhuangzi often uses allegory, metaphor, hyperbole, and absurdity. However, there is a sense in which the correlation between a cosmos out of joint and the oppression perpetuated by sagely ideals and actions may be more than pure exaggeration for rhetorical effect. To more accurately interpret this charge of cosmic derangement that the Zhuangzi brings against the sages, we have to place it within the context of what anthropologists call "Chinese correlative cosmology" or what Michael Nylan describes as "resonance cosmology," which is a profoundly different way of conceiving human, nonhuman, and cosmic agency (Nylan 2016: 100; cf. Descola 2013).

Resonance cosmology consists of myriad techno-epistemological practices for making sense of the interrelations between natural and social changes, natural and social rhythms of existence. They are "cosmological" because these techniques situate politics strictly within the orbit of other natural, nonhuman flows. They observe resonances across musical notes, numbers, colors, gods, spirits, creatures, heavenly bodies, the seasons, and the elements of wood, fire, wind, water, and earth (in the Warring States period). ${ }^{15}$ For instance, a calendar of divination unearthed in Changsha 長沙 in China that dates back to the Warring States lists propitious times for "activities includ[ing] military actions, meeting with other lords for allies, constructing cities and buildings, taking in and marrying off women, ritual ceremonies, and the execution of wicked people." If these activities were carried out at the wrong time,

[T]hey would induce catastrophes and disorder in the universe, including landslides, floods, disorders in the moving patterns of heavenly bodies, abnormal growth of vegetation, unseasonable rain and storms, robbery, and calamities and chaos in the state. These catastrophes and disorders became omens-signs signifying a disruption of the divine cosmic order by human activities. (Wang 2000: 109)

Thus, rulers' actions can lead to natural disasters; conversely, natural disasters can be a sign of deranged governance. Old resonance practices (such as the yin-yang 陰陽, sifang 四方, and wuxing 五行) were often overlaid with new elements in the course

\footnotetext{
${ }^{15}$ See the illuminating table in Wang 2000: 115. For instance, a set of calendrical regulations found in the Shangshu 尚書 (also known as Shujing 書經 or Book of Documents) match the rhythms of the life of the common people ( $\min$ 民) to the seasons: “After the spring equinox is set, the people ( $\mathrm{min}$ ) 'disperse' ( $x i$ 析 ); after the summer solstice, they 'act in accordance' ( $y$ in 因 ); after the autumn equinox, they are 'at ease' ( $y i$ 夷) and after the winter solstice, they 'keep in the warm' ( $y u$ 隩 )" (Kern 2005: 130; cf. Allan 1991).
} 
of imperial, dynastic, and political change. This was partly because these resonance cosmologies legitimized dynasty dominance, even as they constituted a form of techné that guided the government of a territory. ${ }^{16}$

Colonial encounters dismissed these as "superstition" or "primitive thinking" (Clarke 2000: 69; cf. Matthews 2017). However, if one were to insist on a translation into contemporary terms, resonance cosmologies may be seen as ways of mapping the interdependencies of human and more-than-human realms (cf. Puett 2004). Rituals that bound human and cosmic activities were not just religious prescriptions but were de facto laws, as is hinted at in the Zuo Zhuan 左傳 (Commentary of Zuo), which calls war and ritual "the two principal affairs of state" (Chang 1983: 108). The cosmologies were an attempt to use the knowledge of the past to predict the outcomes of possible actions (Chang 1983: 88). Their increasing codification, especially from the Zhou onwards, signaled the consolidation of such techniques of government by the rising shi class. Shi leveraged their knowledge of the exemplary actions of past sage kings to advise rulers (Chang 1983: 80).

The cosmological context implies that a North Atlantic idea of the "ideal" cannot be applied to without qualification to the description of sagely "ideals" in the Zhuangzi. In the Zhuangzi, there is no purely eidetic or Platonic "justice" or "benevolence," nor "oughts" that ought to happen even if they may never come to pass (à la Kant's categorical imperative). Everything is cosmically and politically entwined. This is why, in the Zhuangzi, knowledge or wisdom itself ( $z h i$ 知) can generate cosmopolitical derangement (luan 亂). ${ }^{17}$ Ritual practices (the "tallies" and "seals") embody sagely knowledge, and, in doing so, call forth the disasters they are supposed to avert; sagely ideals (benevolence, righteousness) provoke cosmic catastrophes. This is why the Zhuangzi passes so quickly between things that may appear to us as unrelated, from the tumult of the birds, the animals, and fishes, to the confusion and muddle of the people. Government involves not just the ordering of the human population, but also the ordering of the nonhuman milieu and the biotic realms on which human existence depends.

\section{Against Exemplary Sage-Emperors}

The Zhuangzi's contrarian view of sagely knowledge is reinforced in its treatment of the mythical sage-emperors, Huangdi 黃帝, Yao 堯, and Shun 舜. Outside of the Daoist tradition, they are regarded as exemplary founders of human civilization, of its laws, moral codes, and agricultural orders that separate man from beast (Lewis 2009: 554). Toward these sage-kings, however, the Zhuangzi is at best ambivalent (especially in the case of Huangdi or the Yellow Emperor, who is depicted at times as a seeker of dao and at other times as $U r$-meddler), and mainly critical (Karlgren 1946; Girardot 1988). ${ }^{18}$

\footnotetext{
${ }^{16}$ Wang calls this "the mutual production of cosmology and empire" (Wang 2000: 4).

${ }^{17}$ I have chosen to use the word "derangement" rather than "disorder" or "chaos" for two reasons. First, "chaos" or "disorder" is associated with Hun Dun 混沌, which is prior and/or superior; second, the associations of "chaos" from its Greek etymology renders it problematic and somewhat imprecise for describing the disarray conjured in the Zhuangzi.

${ }^{18}$ On the euhemerism and the mythic and historical dimensions of these sage-emperors, see Lewis 2009, Sellman 1992/1993, and Allan 1981.
} 
The chapter “Letting Be (Zai You 在宥)" follows convention by identifying Huangdi with the beginning of civilization. Yet, civilization is not equated with progress. The Zhuangzi portrays the advent of civilization as the beginning of a general enervation, a long-drawn degeneration:

In ancient times Huangdi first used benevolence and appropriate conduct [ren yi 仁義] to meddle with the minds of men. Yao and Shun followed him and worked till there was no more down on their thighs, no more hair on their shins, trying to nourish the bodies of the men of the world. They grieved their five vital organs in the practice of benevolence and appropriate conduct, taxed their blood and breath in the establishment of laws and standards. But still some men would not submit to their rule, and so they had to exile Huan Dou [讙淣] to Mount Chong 崇, drive away the Sanmiao [三苗] tribes to Sanwei [三峗].... This shows that they could not make the world submit. (Zhuangzi 26/11/19-22; Watson 2013: 76)

Here, benevolence and appropriate conduct are not at all "pacifist." They involve forcible submission, violence to practitioners as well as rebels, and exile of those who chose not to obey.

Likewise, the chapter on "Mending Inborn Nature (Shan Xing 䋨性)" firmly places the appearance of legendary sages, heroes, and legislators, ${ }^{19}$ as well as their actions, as a turn away from a cosmic consonance (or "oneness," $y i-$ ):

In bygone times humans dwelt in crudity and chaos (hun mang 混芒), one with the placid tranquility of the world. At that time the yin and yang were harmonious and still, ghosts and spirits worked no mischief, the four seasons kept to their proper order, all things knew no injury, and no life came to a premature end. Although men had knowledge, they did not use it. This was called oneness [yi-]. At this time, no one acted, and there was unvarying spontaneity [mo zhi wei er chang zi ran 莫之為而常自然.$^{20}$

The time came, however, when virtue [de 德] began to dwindle and decline, and then Sui Ren [燧人] and Fu Xi [伏羲] stepped forward to take charge of the world. As a result there was compliance, but no longer any unity. [...] [T]hen Shen Nong [神農] and the Huangdi stepped forward to take charge of the world. As a result, there was security, but no longer any compliance. [...] [T]hen Yao and Shun stepped forward to take charge of the world. They set about in various fashions to order and transform the world, and in doing so defiled purity and shattered simplicity. The Dao was pulled apart for the sake of goodness; virtue was imperiled for the sake of conduct. [...] the people began to be confused and disordered. They had no way to revert to the true form of their inborn nature [xing 性] or to return once more to the beginning [fu 復]. (Zhuangzi 41/16/5-11; Watson 2013: 123, with modifications)

\footnotetext{
${ }^{19}$ Figures traditionally called “Three Sovereigns and Five Emperors (San Huang Wu Di 三皇五帝)” (Chang 1983: 2).

${ }^{20}$ Here, I have tinkered with Watson's translation; alas it is near impossible to translate $y i$, and I have chosen to go with Nylan's "oneness," although that raises the specter of monotheism.
} 
The section above describes a time that seems to precede the cosmic derangement we examined earlier. Notably, the actions of the sage emperors correspond to a decline, but it is unclear if they actually caused this decline; there is a sense in which the actions of the sage emperors may have been compensatory, though it is ambiguous.

While we cannot be entirely sure, such an interpretation would be in line with the Zhuangzi's unusual portraits of the emperors. We see Huangdi, for instance, seeking wisdom from a mountain hermit; the hermit's words shock Huangdi into relinquishing his throne, and secluding himself in a lonely hut, before returning after three months to ask the hermit a different question (cf. Michael 2015). Instead of a sagely figure who creates order, in that particular narrative Huangdi's desires to master heaven and earth, yin and yang, produce a cosmic disorder that even turns the light of the sun and moon sickly. Instead of a figure of wisdom worthy of emulation, he knows neither what is best for him, nor what is best for the world he would govern.

Thus, to pin the cosmic decline upon the emperors (and their actions) is still to attribute to them a certain potency, even if the potency has negative effects. To refuse to identify them as the source or cause of such decline casts doubt upon the potency traditionally attributed to them. Rather than figures standing above the fray ordering terrestrial flows and human lives, these sage emperors are equally caught up in the cosmic jumble and are scrambling to respond best as they can, even as their responses fall short.

The Zhuangzi's antifoundationalism, in its rejection of the sage emperor as exemplar and role model, rejects by implication their legitimizing function in discourses on rulership.

\section{Playful Speculations on Cook Ding}

This final section ends with a speculative interpretation of the Zhuangzi's famous story of Cook Ding (Pao Ding 㧀丁), who was butchering an ox for Duke Wenhui 文惠 of Wei 魏 (r. 369-319 B.C.E.) (Zhuangzi 7/3/2-8/3/12). As Duke Wenhui, watching Ding, marvels at the cook's skill, the latter lays down his knife, and proceeds, rather surprisingly, to explain his methods of ox carving to Duke Wenhui. He describes how he no longer sees the ox, but follows the daemon (shen 神); sliding his knife through the hollows, he touches no bone, ligament, or tendon; this is why this knife has remained sharp for nineteen years, without needing a whetstone. Ding tells Duke Wenhui how he works with difficult spots, carefully, slowly, and how, with the slightest movement of his knife, the whole thing comes apart like a clod of earth ( $t u$ 土) crumbling to the ground. Instead of rebuking him for insolence, the duke exclaims that the cook has taught him how to nourish life (yang sheng 養生).

The Cook Ding story is often interpreted by Anglophone scholars as a lesson in skillful spontaneity (e.g., Eno 1996, Yearley 1996, Fox 1996, Slingerland 2003, Graham 1989, Hansen 1992, Ivanhoe 1993, Fraser 2014). ${ }^{21}$ This article does not weigh in on these readings, but proposes another interpretive consideration. The Zhuangzi describes how the cook moves rhythmically, "as though he were performing the dance of the Mulberry Grove or keeping time to the 'Jingshou Chorus' of the ancient sage-

$\overline{21}$ For an argument against this dominant interpretation, see Schwitzgebel 2017. 
kings" (Zhuangzi 7/3/4). These were politico-religious rituals, alluding to a rain dance from the Shang 商 dynasty, and music dating back to the rule of Yao respectively (Watson 2013: 50). As one of numerous analogies between governing and cooking found in Warring States and Han 漢 dynasty literature (Sterckx 2011: 49-82), in which the sacrifice of animals and the eating of their flesh in ritual banquets was a way to access the potency of the spirit world, there is a clear allusion here to politics, though the precise point of that allusion remains somewhat elusive. $^{22}$ Given the political and ritual role of sacrifice, the "dietetic and nutritional values associated with food" were fused with and inseparable from their cosmological, religious, and political values (Graziani 2005: 65). Thus, it would not have been implausible for the duke to find an aspect of the culinary arts relevant to his own conduct as political figure.

The duke's observation, that he has learned how to nourish life from a bloody act of butchery, seems rather a non sequitur, at once paradoxical and ironic. There is a hermeneutic gap between the cook's explanations of oxcarving and the duke's profession to have learned how to nourish life from these explanations.

It is true there are ample signals that the cook is not "just" talking about oxcarving (though in the topsy-turvy world of the Zhuangzi perhaps that is not as unimportant a task as one may think). Ding explains that he is one who thirsts for the dao (hao zhe dao 好者道). The thirst for dao is a contrast to the striving for knowledge (hao zhi 好知) of the sages. He does not see the ox, but lets himself be guided by what Graziani calls a clairvoyance (shen 神) (Zhuangzi 7/3/6); Ding's description of the knife's edge having no thickness at all —and if "the joints have spaces within them, and the very edge of the blade has no thickness at all" (Ziporyn 2009: 86) then the blade may "wander" (you 遊) in a vast space-recalls Zeno's paradoxes.

These hints, however, still do not constitute a series of propositions which one can follow to the conclusion, "Ah, so this is how one nourishes life!" What Ding imparts is not a technical form of knowledge that consists of means and ends, for surely it cannot mean that the duke, too, should take up butchery. In other words, even if we are to trust in the insights of the duke's learning, namely, that the cook's statements are indeed about the nurturing of life, it is still unclear how and why exactly that is the case.

There is further the question of whose life it is that the duke has learned to nourish or care for. In this regard, I would like to raise here a couple of related considerations. First, we must be careful about projecting a very specific form of a modern subjectivity or individual onto the Zhuangzi, and this is what C. B. MacPherson has described as

\footnotetext{
22 There are many analogies between governing and cooking that allude to accounts of butchers who became ministers, or cooks who became officials, including in the Huainanzi, Guanzi 管子, and Shiji 史記 (Records of the Grand Historian). Examples are LÜ Wang 呂望 or Taigong Wang 太公望, whom King Wen of Zhou (Zhou Wen Wang 周文王) made a minister, and YI Yin 伊尹, appointed by King Tang 湯 of the Shang dynasty. On whether these are "fictive" or "real" historical personages, see the discussions of euhemerization in Lagerwey and Kalinowski 2009. Officials and stewards overseeing the kitchen and in charge of sacrificial supplies from the Western Zhou to the Warring States and the Han eras wielded considerable political power. They did not have noble status, but were ranked above working craftsmen, and served as gong I or "craft officers" (Powers 2006, cited in Sterckx 2011: 55).
} 
"possessive individualism," in which individuals are imagined as atomistic entities (MacPherson 1962; cf. Chai 2019). ${ }^{23}$ That is to say, our default answer to the question, "Whose, or which, life is nourished?" may be: "The duke's." However, this is not necessarily the Zhuangzi's answer. In the beginning of the chapter that tells Cook Ding's story, the following advice is dispensed:

If you do good, stay away from fame. If you do evil, stay away from punishments. Tend toward the "central meridian," 24 and preserve the body, keep life intact, care for kin [qin 親], and live out the limits of [one's] years. (Zhuangzi 7/3/ 2; Watson 2013: 19, with modifications)

The course of action advised here involves general prescriptions that may apply to diverse roles; the counsel to care for kin shows an acceptance of social and ritual roles. Thus "nourishing life" (yang sheng 養生) may not be restricted to the individual's physiological or personal well-being. ${ }^{25}$

We will begin with the contrast to other conventional analogies made between the culinary and political arts. When Ding encounters a difficult spot, he works carefully, slowly, and with the slightest movement of his knife, the whole thing comes apart like soil or earth ( $t u$ 土) crumbling to the ground. Other culinary analogies use the harmony of "five flavors" (wu wei 五味) to symbolize a partaking of "the cosmos itself," to "ensure the harmonious passage of time and season" (Sterckx 2011: 18), or the judicious measuring of portions of meat to allude to impartial politico-juridical judgment. These are absent in the Cook Ding passage. Instead, Ding's dao of ox carving results in flesh that falls apart onto the ground like so much earth. If the harmony of flavors served as an analogy for cosmic and social harmony, and if proportionality served as an analogy for measured judgment, then what might this analogy of lumpen earth stand for?

One possible interpretation is suggested by the image of earth or soil in the story of Liezi 列子 in the last of the Inner Chapters, "For Emperors and Kings (Ying Di Wang 應 帝王)" ${ }^{26}$ It is too long to recount in full here; what is significant for us is that Liezi, in the process of learning from his master, Huzi 壼子, ${ }^{27}$ finally realizes

\footnotetext{
23 The individual is seen as "essentially the proprietor of his own person or capacities, owing nothing to society for them" (MacPherson 1962: 3). I am not claiming that this is Graziani's understanding, only that it is a mistake we - that is, those trained in the conventions of a North Atlantic academy-risk making. The question is not so much what those men who lived at the time were "really like," as historian and public intellectual Mary Beard has noted about another body of classics, but rather, what concerns and worldviews may be revealed by texts like the Zhuangzi, and other kinds of archaeological and historical research.

${ }^{24}$ Ziporyn explains this medical term in his notes (Ziporyn 2009: 89).

${ }^{25}$ However, even if Ding's statements do teach the duke about personal well-being, this well-being is not limited to the duke's person alone. Livia Kohn explains that in the tradition of longevity techniques (Kohn 2012: 14), health and well-being do not come from care of the self and body alone; there has to be the maintenance, through the senses, emotions, and virtues, of a harmonious flow from the surroundings, of air, food, and social interaction, "families, clans, villages, and states" (Kohn 2012: 5), while Heshanggong Zhangju 河上公章句 (The Heshang Gong Commentary on Laozi's Daodejing) explicitly linked "personal cultivation and the perfection of rulership" (Kohn 2012: 15).

${ }^{26}$ Watson translates this somewhat literally as "Fit for Emperors and Kings," while Ziporyn translates it as "Sovereign Responses for Ruling Powers" (see Ziporyn 2009, Watson 2013).

${ }^{27} \mathrm{Hu}$ 筫 can also refer to the vessel, "pot," which has an empty center, and is an important image in the Daodejing.
} 
$[\mathrm{H}] \mathrm{e}$ had never really begun to learn anything. He went home and for three years did not go out. He replaced his wife at the stove, fed the pigs as though he were feeding people, and showed no preferences in the things he did. He $[\ldots]$ returned to plainness, letting his body stand solitary like a clod [kuai 塊]. ${ }^{28}$ (Zhuangzi 21/7/30-31)

The word kuai 塊 in this context refers to a "lump" or "chunk" of earth. Like $t u$ in the Cook Ding story, kuai $^{29}$ here also invokes a lumpish undifferentiatedness. In the Liezi passage, the roles of male and female, husband and wife (and, by extrapolation, cosmic yin and yang) are turned topsy-turvy, and the differentiations between beasts and humans are effaced.

To return to the narrative of Cook Ding, his ox-carving is not described in the text in terms of measure or proportionality (which symbolize impartiality and fair judgment), nor in terms of a harmony of taste (the symbol for cosmic and human harmony), but in terms of a "wandering" that follows cosmic patterns, resulting in the falling apart of flesh, like so much undifferentiable earth. Despite its association with blood, with death, Ding's butchery teaches the duke how to nourish life. Read in light of the sections cited from the seventh chapter, "For Emperors and Kings," Ding's lesson is perhaps one that advises the duke to not harm a fundamental, cosmic undifferentiatedness in his actions.

The common people, in the Zhuangzi, are by nature (min xing 民性) "simple, crude" (su pu 素樸). The chapter "Horses' Hooves" describes a "time of Perfect Virtue (zhi de 至德)," when the common people lived as one, not split into factions, and shared in the same virtue (tong de 同德) (Zhuangzi 23/9/7); what is more, they "lived together with the birds and beasts, bunched together with all things" (Zhuangzi 23/9/9-11; Watson 2013: 66, with modifications). ${ }^{30}$ The Zhuangzi compares humans in this conditionwhere humans are differentiated neither amongst themselves nor from "birds and beasts"- to unworked wood, raw clay, and wild horses. The attempts on the part of the sages to govern (zhi tian xia 治天下) by benevolence and appropriate conduct (ren yi 仁義) and ritual prescription resemble the efforts of horse tamers to tame wild horseshalf the horses end up dying. It is not in the nature (xing 性) of clay or wood to need the compass and square, curve and plumb line (that potters and carpenters use to shape them). In several chapters $(4,8,9,10)$, the Zhuangzi uses similar technical analogies to criticize the "instruments" of benevolence, appropriate conduct, and ritual prescription that seek to shape human beings and alter their conduct. Thus, "the mutilation of what

\footnotetext{
${ }^{28}$ Liezi's realization that "he had never really begun to learn anything" is, as those familiar with the text will know, far from a negative development. With this realization, Burton Watson thinks Liezi has "reached the highest stage of understanding" (Watson 2013: 97, n.14). We can at least say, to use the words of the Zhuangzi in another chapter, "He who knows he is a fool is not the biggest fool; he who knows he is confused is not in the worst confusion" ("Heaven and Earth (Tiandi 天地)"; Watson 1968: 139). I have left out the final sentence, "In the midst of entanglement he remained sealed, and in this oneness he ended his life" (fen er feng zai, yi yi shi zhong 紛而封哉, 一以是終). This brings us to the questions of death and oneness or union ( $y i-)$, which are themselves the subjects of numerous lengthy scholarly treatments.

${ }^{29}$ The chapter "Discussion on Making All Things Equal (Qi Wu Lun 齊物論)" also refers to kuai: “The Great Clod (da kuai 大 塊) belches out vital energy (qi 氣), and its name is wind" (Zhuangzi 3/2/4; Watson 2013: 7).

${ }^{30}$ The chapter continues with a criticism of sages. As Watson points out in his translation notes, "unpolished simplicity (su pu 素樸)" is also found in chapter 1 of the Daodejing; Hall and Ames have vividly translated the idiom as "unworked wood" (Watson 2013: 66; Ames and Hall 2003: 120, 166).
} 
is crude to fashion implements is the crime of the artisan; the destruction of the dao and its virtuosity (dao de 道德) to instill benevolence and appropriate conduct is the fault of the sage (sheng ren 聖人)" (Zhuangzi 23/9/13-14). However, this brings us to the question of how the Zhuangzi proposes to "return" the common people to their "crude and simple" nature.

Whether or not a paradisiacal or prelapsarian idyll exists in the Zhuangzi (Girardot has claimed it does; see Girardot $1988^{31}$ ), it is, in any case, not possible to "return" to such a state, given the successive interferences of Huangdi, Yao, Shun, and the rest of the sage kings and emperors. Again, though the Zhuangzi prizes a certain crude simplicity that manifests itself in diverse ways in different characters, ${ }^{32}$ there is no one-size-fits-all prescription, unless one counts "following the dao," which is abstract enough to be open - one is tempted to say infinitely - to interpretation. If the common people are by nature crude and simple, then, given that it may well be impossible to "return" them to that state (for it is by no means incontrovertible that the "time of Perfect Virtue [zhi de 至德]" to which the Zhuangzi refers has a sort of chronological precedence), then what is the best way of going about heeding that nature of the people, without adhering to a formula for an impossible ideal?

A nonformulaic possibility is outlined in the ox-carving anecdote. Cook Ding's knife travels the path of least resistance. He contrasts his carving to that of other cooks:

A good cook changes his knife once a year because he cuts. A mediocre cook changes his knife once a month because he hacks. I've had this knife of mine for nineteen years and I've cut up thousands of oxen with it, and yet the blade is as good as though it had just come from the whetstone. (Zhuangzi 7/3/6-8; Watson 2013: 19-20)

Ding does not see an ox, he does not look with his eyes; his is a clairvoyance (shen 神) ${ }^{33}$ guided by cosmic patterns (yi hu tian li 依乎天理). The mediocre cook, because he is unable to sense or abide by cosmic patterns, meets with resistance to his blade, which blunts it. Likewise, one might say that the ruler whose policies provoke the resistance of his populace, and who then subdues that resistance with oppression, is unable to govern according to the "cosmic patterns (tian li 天理)" or nature of the people. Popular resistance is a sign of poor government.

Cook Ding's method of carving allows plenty of room for the "play of the blade." This "play" is significant, for the original Chinese graph that Watson and Ziporyn translate as "play" is you 遊- the same graph that gives us the title of the Zhuangzi's first chapter, "Blithely Wandering (Xiao Yao You 逍遙遊).” You 遊 signifies wandering, without an aim, and as a literary trope, it connotes an "untrammeled and carefree liberation" (Lo 2002: 75). Those who are familiar with the text will already know the indelible image with which that opening chapter begins: a single, miniscule fish roe

\footnotetext{
${ }^{31}$ Cf. Graham's analysis of primitivism, and Puett's and Roth's criticism of Girardot (Graham 2001, Puett 2000, Roth 1985).

32 See, for instance, the passage on undifferentiated Hun Dun (Zhuangzi 21/7/33-35), whom Graham describes as "the primal blob," "a blend of everything rolled together" (Graham 2001: 98-99).

33 Shen 神 is sometimes translated as "spirit," "soul," or "invisible spirit vitality" (Cheng 2009: 78). The closest single English word might be daemon, a vital animating principle, but this then occludes the cosmological schema on which shen rests, and its dependence for instance on $q i$ 氣.
} 
transforms into a magnificent, gargantuan bird that creates a storm with a simple beating of its wings. It is that sort of vast space across oceans, between heaven and earth, that Cook Ding finds in the joints of an ox. To extrapolate, the play across spaces contrasts with the tight networks of laws, regulations, statistics, punishments, surveillance, discipline, and enforcement that underwrote imperial territorialization (McNeal 2017). These dynastic and imperial networks of ritual, economic, political activity were meant to overcome not just geographical and hierarchical distances, but also the resistance of the people. Instead of finding free space, they tightened control across spaces. They were designed in fact to overcome space in order to make possible centralized rule. Thus, just as the unnecessary violence of a mediocre cook's carving blunts the knife, making constant work of changing and sharpening tools, likewise the busyness of imperial governance is related to the control and repression exercised over the people to ensure the latter's obedience. ${ }^{34}$

Thus, though the anecdote of Cook Ding acknowledges the use of technique, it is not technical, in that it cannot simply be instrumentalized or implemented; it transforms the person who uses it, and without this transformation, the "technique" would not work. Hence, the passage turns the question of efficacy away from a perspective of control over external things, to focus on the need for the political figure to attune itself to that on which it seeks to act. The text here allows itself no further prescription than this.

\section{Conclusion}

We have examined the interpretive possibilities of what we categorize today as "political" elements in the Zhuangzi. Its undermining of the heroism associated with exemplary sage-sovereigns (such as Huangdi, Yao, or Shun), its charge that the normative discourses of benevolence and appropriate conduct (ren yi 仁義) are in fact techniques of an oppressive governmentality, may be seen as critical allusions to nascent imperial techniques, and increasing state consolidation.

A note of caution: we must resist erroneously turning the Zhuangzi's critique of proto-imperial logics into affirmations of laissez-faire liberalism, or libertarianism. Not only would such a translation be anachronistic, it would also contradict the Zhuangzi's lessons on the complicity of elite ideals with oppressions of different kinds. Laissezfaire liberalism and libertarianism are culturally and historically specific ideas that rest upon presuppositions concerning the nature of the individual and society, and, as postcolonial and decolonial writers point out, the ideas themselves are not free of histories of domination, violence, and colonial suppression that have underwritten their dissemination (Chakrabarty 2000, Lowe 2015). Further, although the practice of wuwei 無為 (in the Zhuangzi as well as the Daodejing) has been translated as "doing nothing" (Graham 1989), "nonaction" (Chan 2017), or "non-purposive action" (Schwartz 1985), when used in a political context it should not be misread as advocacy for a simple hands-off or night-watchman state approach. The practice of wuwei, when specifically linked to political claims, for instance in the Outer Chapter “Letting Be (Zai You 在宥)," involves virtuosity, ethical practice, and a profound understanding of the "nature" (xing

\footnotetext{
$\overline{34}$ There are echoes of this critique in the Daodejing's reference to xuan de 玄德 (“dark virtue” [Lau 1994] or "profoundest efficacy" [Ames and Hall 2003]; see chapter 10 of the Daodejing).
} 
性) of things (cf. Lai 2007, Chan 2006, Chai 2014), and in particular, an understanding of min xing 民性 or the “commoners' nature.” The precise conjunction of these different tropes, however, requires further study and cannot be adequately dealt with here. Thus, this article does not take a stand on the question of whether the Zhuangzi provides normative or moral grounds for political action or not.

The Zhuangzi's reticence, if not downright recalcitrance, may well stem from the fact that "the Zhuangzi's masters [ $z i$ 子] seem to have an intuition that gets lost as soon as one tries to turn it into a moral system or formal training" (Defoort 2012: 476). Further, the Zhuangzi's refractory stance can be understood in light of its audiencethose who would have been capable of deciphering the text would have been precisely the ones charged with implementing the oppressions we have seen. The Zhuangzi does not shy away from "political" efficacy as such. In fact, some of its passages boast of a consummate, unparalleled efficaciousness. However, the text short-circuits every attempt to turn its insights into techniques or methods that can be replicated, applied, or instrumentalized. Contemporary scholars will be all too familiar with this deliberate short-circuiting-witness all our tortured attempts to unravel the paradoxes of wuwei. Thus, though the body of work was ultimately absorbed into the discourses of Han imperial scholarship, within certain strands of the Zhuangzi, one may discern a drive to disrupt a nascent imperial discourse, and a performative circumvention of the "virtues" of an emerging imperialism.

Acknowledgments The author would like to thank TAN Sor Hoon, Alan Chan, Leigh Jenco, the editor and anonymous reviewers of Dao, as well as participants of the Philosophy Colloquium of the Philosophy Department, Nanyang Technical University (Singapore, August 2017) for their helpful suggestions for this article. Open access publication of this article has been made possible by Cardiff University.

Open Access This article is distributed under the terms of the Creative Commons Attribution 4.0 International License (http://creativecommons.org/licenses/by/4.0/), which permits unrestricted use, distribution, and reproduction in any medium, provided you give appropriate credit to the original author(s) and the source, provide a link to the Creative Commons license, and indicate if changes were made.

\section{References}

Allan, Sarah. 1981. "Shang Foundations of Modern Chinese Folk Religion." In Chinese Ritual and Politics, edited by E. Ahern. Cambridge: Cambridge University Press.

1991. The Shape of the Turtle: Myth, Art, and Cosmos in Early China. Albany: SUNY Press.

Allinson, Robert Elliott. 2015. "Of Fish, Butterflies and Birds: Relativism and Nonrelative Valuation in the Zhuangzi." Asian Philosophy: An International Journal of the Philosophical Traditions of the East 25.3: $238-252$.

Ames, Roger, and David Hall. 2003. Dao De Jing. New York: Ballantine Books, Random House.

Billioud, Sebastien, and Joël Thoraval. 2015. The Sage and the People: The Confucian Revival in China. Oxford: Oxford University Press.

Boltz, Judith Magee. 2001. “Taoist Heritage.” In Columbia History of Chinese Literature, edited by Victor H. Mair. New York: Columbia University Press.

Buckley, Chris. 2014. "Leader Taps Into Chinese Classics in Seeking to Cement Power." New York Times, October 11. https://www.nytimes.com/2014/10/12/world/leader-taps-into-chinese-classics-in-seeking-tocement-power.html (last accessed on May 16, 2019).

Chai, David. 2014. "Daoism and Wu 無." Philosophy Compass 9.10: 663-671. DOI: https://doi.org/10.1111 /phc3.12171 
2019. "Nothingness and Selfhood in the Zhuangzi." In Bloomsbury Research Handbook of Early Chinese Ethics and Political Philosophy, edited by Alexus McLeod, Chakravarthi Ram-Prasad, and TAN Sor Hoon. London: Bloomsbury.

Chakrabarti, Arindam, and Ralph Weber, eds. 2016. Comparative Philosophy without Borders. London and New York: Bloomsbury.

Chakrabarty, Dipesh. 2000. Provincializing Europe: Postcolonial Thought and Historical Difference. Princeton: Princeton University Press.

Chan, Alan K. L. 2002. "Guo Xiang.” In Encyclopedia of Chinese Philosophy, edited by Antonio S. Cua. New York: Routledge.

2006. "Review: Scott Cook (ed.). Hiding the World in the World: Uneven Discourses on the Zhuangzi." Monumenta Serica 54: 530-533.

2017. "Laozi." In Stanford Encyclopedia of Philosophy Archive (Spring 2017 Edition), edited by Edward

N. Zalta. https://plato.stanford.edu/archives/spr2017/entries/laozi/ (last accessed on May 17, 2019).

Chang, Kwang Chih. 1983. Art, Myth, and Ritual: The Path to Political Authority in Ancient China. Cambridge, MA: Harvard University Press.

Cheng, Chung-ying. 2009. "The Yi-Jing and Yin-Yang Way of Thinking." In The Routledge History of World Philosophies: History of Chinese Philosophy, edited by Bo Mou. London and New York: Routledge.

Chinn, Ewing Y. 1997. "Zhuangzi and Relativistic Skepticism.” Asian Philosophy: An International Journal of the Philosophical Traditions of the East 7.3: 207-220.

Clarke, J. J. 2000. The Tao of the West: Western Tranformations of Taoist Thought. London and New York: Routledge.

Coutinho, Steve. 2013. An Introduction to Daoist Philosophies. New York: Columbia University Press.

Crane, Sam. 2013. Life, Liberty, and the Pursuit of Dao. Chichester, West Sussex: John Wiley and Sons.

Dallmayr, Fred. 1997. "Introduction: Toward a Comparative Political Theory." The Review of Politics 59.3: 421-427.

De Reu, Wim. 2015. "A Ragbag of Odds and Ends? Argument Structure and Philosophical Coherence in Zhuangzi 26." In Literary Forms of Argument in Early China, edited by Joachim Gentz and Dirk Meyer. Leiden: Brill.

Defoort, Carine. 2001. "Is There Such a Thing as Chinese Philosophy? Arguments of an Implicit Debate." Philosophy East and West 51.3: 393-413.

2012. "Instruction Dialogues in the Zhuangzi: An 'Anthropological' Reading." Dao: A Journal of Comparative Philosophy 11.4: 459-478.

Descola, Philippe. 2013. Beyond Nature and Culture. Trans. by J. Lloyd. Chicago: University of Chicago Press.

Eno, Robert. 1996. "Cook Ding's Dao and the Limits of Philosophy.” In Essays on Skepticism, Relativism and Ethics in the Zhuangzi, edited by Paul Kjellberg and Philip J. Ivanhoe. Albany: SUNY Press.

Euben, Roxanne L. 2006. Journeys to the Other Shore: Muslim and Western Travelers in Search of Knowledge. Princeton: Princeton University Press.

Fox, Alan. 1996. "Reflex and Reflectivity: Wuwei in the Zhuangzi." Asian Philosophy 6.1: 59-72.

Fraser, Chris. 1997. "Review Article: Classifying the Zhuangzi Chapters." Asian Philosophy 7.2: 155-159. 2009. "Skepticism and Value in the Zhuangzi." International Philosophical Quarterly 49.4: 439-457. 2014. "Wandering the Way: A Eudaimonistic Approach to the Zhuāngzĭ." Dao: A Journal of Comparative Philosophy 13.4: 541-565.

2015. "Zhuangzi and the Heterogeneity of Value." In New Visions of the Zhuangzi, edited by Livia Kohn. St. Petersburg, FL: Three Pines Press.

Gentz, Joachim, and Dirk Meyer, eds. 2015. Literary Forms of Argument in Early China. Leiden: Brill.

Girardot, Norman. 1988. Myth and Meaning in Early Taoism. Berkeley: University of California Press.

Graham, Angus C. 1989. Disputers of the Tao. La Salle: Open Court.

2001. Chuang Tzu: The Inner Chapters. Indianapolis: Hackett Publishing.

2003. “How Much of Chuang Tzu Did Chuang Tzu Write?” In A Companion to Angus C. Graham's Chuang Tzu, edited by Harold Roth. Honolulu: University of Hawai'i Press.

Graziani, Romain. 2005. "When Princes Awake in Kitchens: Zhuangzi's Rewriting of a Culinary Myth.” In Of Tripod and Palate: Food, Politics, and Religion in Traditional China, edited by Roel Sterckx. New York: Palgrave Macmillan.

Hansen, Chad. 2003. "Guru or Skeptic? Relativistic Skepticism in the Zhuangzi." In Hiding the World in the World: Uneven Discourses on the Zhuangzi, edited by Scott Cook. Albany: SUNY Press.

Hansen, Chad. 1992. A Daoist Theory of Chinese Thought: A Philosophical Interpretation. New York: Oxford University Press.

Henricks, Robert G., trans. 1989. Lao Tzu: Te-Tao Ching. New York: Ballantine, Random House. 
Hsu, Cho Yun. 1999. "The Spring and Autumn Period.” In The Cambridge History of Ancient China: From the Origins of Civilization to 221 B.C., edited by Michael Loewe and Edward L. Shaughnessy. Cambridge: Cambridge University Press.

Hung, William, ed. 1956. A Concordance to Chuang Tzu 莊子引得. Harvard-Yenching Institute Sinological Index Series, Supplement No. 20. Cambridge, MA: Harvard University Press.

Israel, George L. 2016. "The Renaissance of WANG Yangming Studies in the People's Republic of China." Philosophy East and West 66.3: 1001-1019.

Ivanhoe, Philip J. 1993. "Zhuangzi on Skepticism, Skill, and the Ineffable Dao." Journal of the American Academy of Religion 61.4: 639-654.

Jenco, Leigh, ed. 2017. Special Issue: Confucianism and Its Contexts: European Journal of Political Theory 16.4 .

Jiang, Tao. 2016. "The Problem of Authorship and the Project of Chinese Philosophy: ZhuAng Zhou and the Zhuangzi between Sinology and Philosophy in the Western Academy." Dao: A Journal of Comparative Philosophy 15.1: 35-55.

Karlgren, Bernhard. 1946. "Legends and Cults in Ancient China." Bulletin of the Museum of Far Eastern Antiquities 18: 199-366.

Kern, Martin. 2005. "Poetry and Religion: The Representation of 'Truth' in Early Chinese Historiography." In Historical Truth and Historical Criticism and Ideology: Chinese Historiography and Historical Culture from a New Comparative Perspective, edited by Helwig Schmidt-Glinzer, Achim Mittag, and Jörn Rüsen. Leiden and Boston: Brill.

Kjellberg, Paul, and Philip J. Ivanhoe, eds. 1996. Essays on Skepticism, Relativism, and Ethics in the Zhuangzi. Albany: SUNY Press.

Klein, Esther. 2011. "Were There 'Inner Chapters' in the Warring States? A New Examination of Evidence about the Zhuangzi." T'oung Pao 96: 299-369.

Kohn, Livia. 2012. A Source Book in Chinese Longevity. St. Petersburg, FL: Three Pines Press.

Lagerwey, John, and Marc Kalinowski, eds. 2009. Early Chinese Religion: Part One: Shang through Han (1250 BC-220 AD). Leiden and Boston: Brill.

Lai, Karyn. 2007. "Ziran and Wuwei in the Daodejing: An Ethical Assessment." Dao: A Journal of Comparative Philosophy 6.4: 325-337.

Larson, Gerald James. 1988. "Introduction: The 'Age-Old Distinction between the Same and the Other'." In Interpreting Across Boundaries: New Essays in Comparative Philosophy, edited by Gerald James Larson and Eliot Deutsch. Princeton: Princeton University Press.

Lau, D. C., trans. 1994. Tao Te Ching. New York: Alfred A. Knopf.

Legge, James. 1891. The Writings of Chuang Tzu. In Chinese Text Project, edited by Donald Sturgeon. https://ctext.org/zhuangzi (last accessed on May 27, 2019).

Lewis, Mark Edward. 1999a. Writing and Authority in Early China. Albany: SUNY Press.

1999b. "Warring States: Political History." In The Cambridge History of Ancient China: From the Origins of Civilization to 221 B.C., edited by Michael Loewe and Edward L. Shaughnessy. Cambridge: Cambridge University Press.

2009. "The Mythology of Early China." In Early Chinese Religion: Part One: Shang through Han (1250 BC-220 AD), edited by John Lagerwey and Marc Kalinowski. Leiden and Boston: Brill.

Lin, Shuen-Fu. 2003. "Transforming the Dao: A Critique of A. C. Graham." In Hiding the World in the World: Uneven Discourses on the Zhuangzi, edited by Scott Cook. Albany: SUNY Press.

Liu, Xiaogan. 1994. Classifying the Zhuangzi Chapters. Trans. by William E. Savage. Ann Arbor: University of Michigan Press.

Lo, Y. K. 2002. "Wandering and Imaginal Realms in the Analects and Zhuangzi." Monumenta Serica 50: 7593.

Lowe, Lisa. 2015. The Intimacies of Four Continents. Durham and London: Duke University Press.

MacPherson, C. B. 1962. The Political Theory of Possessive Individualism: Hobbes to Locke. Oxford: Oxford University Press.

Mair, Victor H. 1994. Wandering on the Way: Early Taoist Tales and Parables of Chuang Tzu. Honolulu: University of Hawai'i Press.

2001. "Introduction: The Origins and Impact of Literati Culture." In The Columbia History of Chinese Literature, edited by Victor H. Mair. New York: Columbia University Press.

Major, John S., Sarah A. Queen, Andrew Seth Meter, and Harold D. Roth, trans. and edited. 2010. The Huainanzi: A Guide to the Theory and Practice of Government in Early Han China. New York: Columbia University Press.

Matthews, William. 2017. "Ontology with Chinese Characteristics: Homology as a Mode of Identification." Hau: Journal of Ethnographic Theory 7.1: 265-285. 
McNeal, Robin. 2017. "Spatial Models of the State in Early Chinese Texts: Tribute Networks and the Articulation of Power and Authority in Shangshu 'Yu Gong' 禹貢 and Yi Zhoushu 'Wang Hui' 王會." In Origins of Chinese Political Philosophy: Studies in the Composition and Thought of the Shangshu (Classic of Documents), edited by Martin Kern and Dirk Meyer. Leiden: Brill.

Michael, Thomas. 2015. "Hermits, Mountains, and Yangsheng in Early Daoism: Perspectives from the Zhuangzi." In New Visions of the Zhuangzi, edited by Livia Kohn. St. Petersburg, FL: Three Pines Press.

Needham, Joseph. 1956. Science and Civilization in China, vol. 2: History of Scientific Thought. Cambridge: Cambridge University Press.

Nelson, Eric. 2008. "Questioning Dao: Skepticism, Mysticism, and Ethics in the Zhuangzi." International Journal of the Asian Philosophical Association 1: 11-22.

Nylan, Michael. 2016. "Academic Silos, or 'What I Wish Historians Knew About Early History in China'.” In The Bloomsbury Handbook of Chinese Research Methodologies, edited by TAN Sor-Hoon. London and New York: Bloomsbury.

Perkins, Franklin. 2014. Heaven and Earth Are Not Humane: The Problem of Evil in Classical Chinese Philosophy. Bloomington: Indiana University Press.

Powers, Martin. 2006. Pattern and Person: Ornament, Society, and Self in Classical China. Cambridge, MA: Harvard University Asia Center.

Puett, Michael J. 2000. "Violent Misreadings: The Hermeneutics of Cosmology in Huainanzi." Bulletin of the Museum of Far Eastern Antiquities 72: 29-47.

2001. The Ambivalence of Creation: Debates Concerning Innovation and Artifice in Early China. Stanford: Stanford University Press.

2004. To Become a God: Cosmology, Sacrifice, and Self-divinization in Early China. Cambridge, MA: Harvard University Press.

Raphals, Lisa. 1994a. "Poetry and Argument in the Zhuangzi." Journal of Chinese Religions 22: 103-116. 526. 1994b. "Skeptical Strategies in the Zhuangzi and Theaetetus." Philosophy East and West 44.3: 501-

Roth, Harold D. 1985. "Review: N. Girardot. Myth and Meaning in Early Taoism." Journal of the Royal Asiatic Society 2: 234-238.

2015. "Daoist Apophatic Meditation: Selections from the Classical Daoist Textual Corpus." In Contemplative Literature: A Comparative Sourcebook on Meditation and Contemplative Prayer, edited by Louis Komjathy. Albany: SUNY Press.

Schwartz, Benjamin I. 1985. The World of Thought in Ancient China. Cambridge, MA: Belknap; Harvard University Press.

Schwitzgebel, Eric. 2017. "The Unskilled Zhuangzi: Big and Useless and Not So Good at Catching Rats." Draft. http:/www.faculty.ucr.edu/ eschwitz/SchwitzAbs/ZZSkill.htm (last accessed on May 17, 2019).

Sellman, James. 1992/1993. "On the Myth of Cosmogony in Ancient China." Analecta Husserliana 47: 211220.

Slingerland, Edward. 2003. Effortless Action: Wu-wei as Conceptual Metaphor and Spiritual Ideal in Early China. Oxford: Oxford University Press.

Soles, Deborah H., and David E. Soles. 1998. "Fish Traps and Rabbit Snares: Zhuangzi on Judgement, Truth and Knowledge." Asian Philosophy: An International Journal of the Philosophical Traditions of the East 8.3: $149-164$.

Sterckx, Roel. 2011. Food, Sacrifice and Early Sagehood in China. Cambridge: Cambridge University Press.

Sturgeon, Donald. 2015. “Zhuangzi, Perspectives, and Greater Knowledge.” Philosophy East and West 65.3: 892-917.

Tan, Sor Hoon, ed. 2016. The Bloomsbury Research Handbook of Chinese Philosophy Methodologies. New York: Bloomsbury.

Tilly, Charles. 1985. "War Making and State Making as Organized Crime." In Bringing the State Back In, edited by Peter Evans, Dietrich Rueschemeyer, and Theda Skocpol. Cambridge: Cambridge University Press.

Van Norden, Bryan. 2015. "China's Apolitical School of Thought.” The National Interest, May 7. http://nationalinterest.org/feature/chinas-apolitical-political-school-thought-12823 (last accessed on May 17, 2019).

2016. "Zhuangzi's Ironic Detachment and Political Commitment." Dao: A Journal of Comparative Philosophy 15.1: 1-1:17.

Wang, Aihe. 2000. Cosmology and Political Culture in Early China. Cambridge: Cambridge University Press. Watson, Burton, trans. 2013. The Complete Works of Zhuangzi. New York: Columbia University Press.

Williams, Melissa S., and Mark E. Warren. 2014. "A Democratic Case for Comparative Political Theory." Political Theory 42.1: 26-57. 
Yearley, Lee H. 1996. “Zhuangzi's Understanding of Skillfulness and the Ultimate Spiritual State.” In Essays on Skepticism, Relativism and Ethics in the Zhuangzi, edited by Paul Kjellberg and Philip J. Ivanhoe. Albany: SUNY Press.

Yu, Pauline, Peter Bol, Stephen Owen, and Willard Peterson, ed. 2000. Ways with Words: Writing about Reading Texts from Early China. Berkeley: University of California Press.

Zhang, Qizhi. 2015. An Introduction to Chinese History and Culture. Heidelberg: Springer.

Ziporyn, Brook. 2003. "How Many Are the Ten Thousand Things and I? Relativism, Mysticism, and the Privileging of Oneness in the Inner Chapters." In Hiding the World in the World: Uneven Discourses on the Zhuangzi, edited by Scott Cook. Albany: SUNY Press.

Ziporyn, Brook, trans. 2009. Zhuangzi: The Essential Writings with Selections from Traditional Commentaries. Indianapolis: Hackett.

Publisher's Note Springer Nature remains neutral with regard to jurisdictional claims in published maps and institutional affiliations. 